\title{
PERSEPSI NILAI DAN KUALITAS HUBUNGAN TERHADAP CCB DENGAN MEDIASI KEPUASAN PELANGGAN PADA TRANSPORTASI ONLINE GRAB DI SURABAYA
}

\author{
Aribah Rihadatul Aisy \\ Magister Management Program of STIE Perbanas Surabaya \\ aisyaribah@gmail.com \\ Tatik Suryani \\ Magister Management Program of STIE Perbanas Surabaya \\ tatik@perbanas.ac.id
}

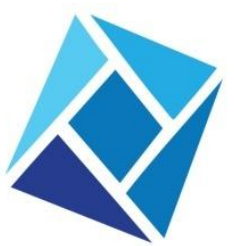

\section{Jurnal Nusantara Aplikasi Manajemen Bisnis}

http://ojs.unpkediri.ac.id/index. php/manajemen/index

E-ISSN : 2528-0929

P-ISSN : 2549 - 5291

Diterima: 6 Juli 2019

Revisi : 8 Agustus 2019

Disetujui: 24 Oktober 2019

https://DOI

10.29407/nusamba.v4i2.13161
Abstract

This study was aimed to determine The Effect Of Perceived Value and Relationship Quality Towards Customer Citizenship Behavior (CCB) to Online Transportation Grab in Surabaya: With Satisfaction as an Intervening Variable. The samples of this study is 200 people who used Grab in Surabaya and collecting data was conduct by questionaires distributed directly to the respondent. Sample were analyzed by purposive sampling technique with non probability sampling methods. The statistical method used PLS followed by software WarpPLS. The result of this study showed that Customer satisfaction partially influences mediation on the relationship quality with Customer Citizenship Behavior (CCB). Furthermore, Customer satisfaction does not have a partial or overall mediating effect on the Perceived Value with Customer Citizenship Behavior (CCB).

Key words: Perceived Value, Relationship Quality, Customer Citizenship Behavior (CCB), Grab

\section{Abstrak}

Penelitian ini bertujuan untuk mengetahui Pengaruh Persepsi Nilai dan Kualitas Hubungan terhadap CCB dengan mediasi Kepuasan Pelanggan pada Transportasi Online Grab di Surabaya. Variabel pada penelitian ini yaitu Kualitas Hubungan dan Persepsi Nilai sebagai variabel bebas, Kepuasan Pelanggan sebagai variabel mediasi dan perilaku kewargaan pelanggan sebagai variabel terikat, dimana pada artikel ini variabel Perilaku Kewargaan Pelanggan disebut CCB. Sampel penelitian ini adalah 200 orang yang menggunakan Grab di Surabaya dan pengumpulan data dilakukan dengan melakukan penyebaran kuesioner yang dibagikan langsung kepada responden. Sampel dianalisis dengan teknik purposive sampling dengan metode non probability sampling. Metode analisis data yang digunakan yaitu dengan PLS yang dibantu dengan software WarpPLS. Hasil penelitian ini menunjukkan bahwa kepuasan pelanggan secara parsial memediasi pengaruh kualitas hubungan dengan CCB. Selain itu, kepuasan Pelanggan tidak memiliki efek mediasi secara parsial atau keseluruhan pada persepsi nilai dengan CCB.

Kata kunci: Persepsi Nilai, Kualitas Hubungan, Perilaku Kewargaan Pelanggan (CCB), Grab. 


\section{PENDAHULUAN}

Perilaku kewargaan pelanggan (CCB) dianggap penting bagi perusahaan, karena dengan adanya CCB dinilai dapat membantu keberhasilan sebuah perusahaan. Salah satu contoh perilaku sukarela yang dilakukan oleh pelanggan yaitu dengan merekomendasikan, mengatakan hal-hal positif mengenai layanan Grab. Bagi pihak penyedia transportasi online Grab CCB sangat berarti bagi perusahaan. Oleh karena itu, Grab harus lebih mendorong pelanggannya untuk terlibat secara langsung dalam melakukan CCB.

Tindakan pelanggan yang bersifat pro-sosial terhadap layanan Grab, dapat digunakan oleh perusahaan untuk terus meningkatkan nilai tambah (value added) yang ada pada layanan Grab. Nilai bagi pelanggan dapat menjadi kinerja yang unggul bagi layanan Grab. Oleh karena itu, Grab terus berupaya untuk meningkatkan persepsi nilai pada pelanggannya seperti, membangun platform online to offline pada konsumen sehingga konsumen dapat mengakses layanan Grab lebih aman dan dapat diandalkan melalui akses pembayaran nontunai dan akses layanan online maupun e-commerce.

Grab merupakan pelopor dalam memprioritaskan keamanan para pelanggannya pada perjalanan ride-hailing melalui fitur yang mereka miliki seperti Share My Ride. Dengan adanya fitur tersebut diharapkan dapat meningkatkan keamanan dan keselamatan bagi para pelanggan dan mitra pengemudi layanan Grab, selain itu fitur share my ride diharapkan dapat menciptakan persepsi nilai pelanggan yang tinggi sehingga konsumen yang telah merasakan nilai positif dari layanan transportasi online Grab akan merasa puas dan akan menunjukkan CCB kepada orang lain.

Berdasarkan data yang bersumber dari comScore pada bulan Desember tahun 2017, tercatat sebanyak 15,73 juta orang di Indonesia telah menggunakan aplikasi transportasi online di ponsel mereka. Transportasi online tersebut antara lain yaitu Gojek dan Grab. Kedua transportasi berbasis online tersebut saling bersaing untuk mendapatkan pelanggan baru dengan menawarkan layanan terbaik dan fitur yang mereka miliki. Gojek dan Grab yang merupakan bagian dari transportasi berbasis online ini, membuat banyak perusahaan lain untuk ikut serta dalam mengambil peluang untuk menciptakan usaha ojek online. Sebagai perbandingan pengguna transportasi online, comScore mobile matrix melakukan analisis data. Hasilnya yaitu pada bulan Desember tahun 2017 jumlah pengguna aktif layanan Gojek yaitu sebesar 9,7 juta orang yang mengakses layanan Gojek. Kemudian disusul dengan Grab yaitu sebesar 9,6 juta orang yang mengakses layanan Grab. Berdasarkan data jumlah pengguna layanan transportasi online tersebut, menunjukkan jumlah pengguna layanan Grab yang semakin meningkat dari tahun ke tahun. Namun, peningkatan jumlah pengguna layanan Grab masih rendah apabila dibandingkan dengan kompetitornya yaitu Gojek.

Grab terus berupaya untuk membangun kualitas hubungan yang baik dengan para penggunanya karena kualitas hubungan sangat diperlukan oleh perusahaan untuk mengembangkan hubungan jangka panjang dengan pelanggan khusunya pengguna transportasi online Grab (Barry \& Terry dalam M. S. Balaji, 2014). Hubungan yang menawarkan kualitas yang unggul akan menciptakan kepuasan bagi para pengguna layanan Grab. Pihak Grab harus lebih memahami faktor-faktor yang mempengaruhi hubungan pelanggan dengan perusahaan. Salah satu upaya yang dilakukan oleh Grab yaitu terus meningkatkan keamanan bagi para pengguna layanan Grab dan mitra pengemudi layanan Grab. Selain itu, Grab juga terus melakukan edukasi maupun pelatihan kepada para mitranya sehingga mereka dapat mengetahui cara untuk menjalin hubungan yang baik dengan pelanggan Grab. Dengan adanya hal tersebut, diharapkan Grab dapat mempertahankan kualitas hubungan yang baik antara Grab dengan penggunanya. 
Kehadiran Grab sangatlah menguntungkan bagi masyarakat, karena dengan adanya layanan tersebut masyarakat tidak perlu repot jika akan berpergian ke suatu tempat. Kemudahan penggunaan aplikasi Grab yang dirasakan oleh pelanggan dimana ekspektasi mengenai kemudahan penggunaan aplikasi transportasi online melebihi ekspektasi yang dibuat oleh pelanggan maka pelanggan akan merasa puas terhadap kemudahan dalam penggunaan aplikasi Grab. Pengguna layanan Grab yang telah merasakan manfaat terhadap nilai yang ada pada layanan Grab, maka mereka akan berpersepsi bahwa Grab merupakan sebuah layanan yang memiliki nilai bagi mereka. Selanjutnya, persepsi yang telah dibuat oleh pelanggan Grab akan menjadi kepuasan dari pelanggan Grab. Apabila pelanggan Grab merasa puas dengan layanan Grab maka layanan tersebut akan diterima oleh pelanggan dan melekat pada perusahaan. Pelanggan yang telah merasakan manfaat melalui layanan Grab akan membalas dan memberikan umpan balik kepada perusahaan dengan CCB.

\section{KERANGKA TEORITIS YANG DIPAKAI DAN HIPOTESIS Kualitas Hubungan}

Kualitas hubungan dapat didefinisikan sebagai tingkat kelayakan suatu hubungan antara perusahaan dengan pelanggan untuk memenuhi kebutuhan para pelanggan. Menurut Jap, Manolis dan Weitz (1999), dalam Balaji (2014), kualitas hubungan seharusnya menyertakan konstruk yang menggambarkan "proses sikap dan harapan pada masa depan" dari hubungan yang terjadi pada pembeli dan penjual. Konstruk dari kualitas hubungan (Balaji, 2014) meliputi faktor tingkat tinggi dari kepercayaan, kepuasan dan komitmen.

Kualitas hubungan yang baik akan memperbesar komitmen, kepercayaan, hubungan jangka panjang yang berkelanjutan antara pelanggan dan perusahaan. Kualitas hubungan yang terjalin dengan baik juga dapat menurunkan level konflik yang mungkin terjadi antara pelanggan dengan perusahaan.

Karakteristik perusahaan yang baik dapat dilihat melalui kemampuan perusahaan dalam membangun kualitas hubungan yang baik dengan pelanggan. Salah satu cara yang dapat dilakukan oleh perusahaan untuk membangun kualitas hubungan dengan pelanggan yaitu dengan membangun komunikasi yang cepat dan akurat dengan pelanggan. Apabila perusahaan membangun kualitas hubungan yang baik dengan pelanggan maka pelanggan akan menganggap bahwa perusahaan merespon dan menyelesaikan keluhan pelanggan dengan baik. (Matti Juhani Haverila, Mia Martinsuo \& Earl Naumann, 2014).

\section{Persepsi Nilai}

Persepsi nilai merupakan penilaian secara menyeluruh yang dilakukan oleh konsumen terhadap kegunaan suatu produk atau layanan yang didasarkan pada persepsi tentang apa yang diterima oleh konsumen dan apa yang dirasakan oleh konsumen (Zeithaml, 1988 dalam Weisheng Chiu, Sunyun Shin \& Hyun-Woo Lee, 2017).

Konsep nilai dari persepsi pelanggan dapat didefinisikan dari berbagai perspektif. Pertama yaitu, perspektif ekonomi dimana pelanggan mempersepsikan nilai dengan biaya yang dibebankan oleh penyedia layanan, apabila biaya yang dibebankan penyedia layanan kepada pelanggan lebih rendah dibandingkan dengan pesaing maka nilai pelanggan terhadap penyedia layanan juga akan tinggi. Kedua yaitu perspektif nilai emosional, pelanggan akan melakukan keputusan untuk melakukan pembelian kembali atau menggunakan kembali layanan perusahaan berdasarkan perasaan positif pelanggan yang dihasilkan oleh sebuah layanan perusahaan. Ketiga yaitu nilai sosial, perasaan positif yang dirasakan oleh pelanggan setelah menggunakan layanan perusahaan dapat meningkatkan konsep diri pelanggan terhadap layanan perusahaan (Rizwan Ali et al, 2015). 


\section{Kepuasan Pelanggan}

Kepuasan pelanggan merupakan evaluasi secara subjektif yang dilakukan oleh pelanggan terhadap situasi yang menghasilkan respon emosional yang positif. Kepuasan pelanggan memainkan peran penting dalam kelangsungan hidup dan menjadi profitabilitas jangka panjang bagi perusahaan.

Kepuasan atau ketidakpuasan yang dirasakan oleh pelanggan merupakan reaksi kognitif atau afektif yang muncul sebagai respon terhadap satu atau beberapa kali pertemuan layanan. Kepuasan pelanggan juga seringkali dianggap sebagai kunci sukses perusahaan dan daya saing jangka panjang perusahaan terhadap para kompetitornya. (Ilias Santouridis \& Androniki Veraki, 2017).

Kepuasan pelanggan dapat digambarkan sebagai kondisi kognitif dimana konsumen merasa terpenuhi atau tidak dalam penggunaan jasa perusahaan serta pengorbanan yang telah mereka lakukan dalam penggunaan jasa perusahaan sesuai dengan keinginan dan kebutuhan konsumen. Keadaan psikologis yang dihasilkan oleh konsumen berasal dari emosi disekitar ekspektasi yang tidak dapat dikonfirmasi ditambah dengan perasaan konsumen tentang pengalamaan penggunaan jasa perusahaan yang buruk, selain itu kondisi psikologis konsumen juga dapat dilihat melalui kesenangan atau kekecewaan yang timbul dengan cara membandingkan kinerja yang dirasakan sesuai dengan harapan yang telah mereka buat.

\section{Customer Citizenship Behavior (CCB)}

Pelanggan sering terlibat dalam perilaku sukarela yang tidak diperlukan tetapi perilaku tersebut dianggap sebagai bantuan secara sukarela yang datang dari pelanggan kepada perusahaan. . CCB juga dianggap sebagai salah satu faktor yang secara tidak langsung dapat menentukan keberhasilan perusahaan melalui tindakan secara sukarela yang dilakukan oleh pelanggan untuk menginformasikan atau merekomendasikan produk atau jasa kepada pelanggan lain maupun kepada pelanggan yang sudah menggunakan produk atau jasa dari sebuah perusahaan.

CCB termasuk tindakan komunikasi informal yang menguntungkan mengenai aspek organisasi, hubungan afiliasi (menggunakan tampilan nyata atau barang pribadi untuk berhubungan dan berkomunikasi dengan organisasi, memberikan saran atau perbakan terhadap sebuah layanan, layanan komunikasi yang berhubungan dengan perbaikan atau peningkatan layanan perusahaan atas kegagalan yang dialami oleh organisasi. CCB ini berkaitan dengan perilaku ekstra positif yang ditampilkan oleh pelanggan yang akan berkontribusi bagi kesuksesan organisasi. (Bove Robertson et al, 2003:332 dalam Estelle van Tonder dan Leon T. de Beer, 2018).

\section{Pengaruh Kualitas Hubungan terhadap Customer Citizenship Behavior (CCB)}

Salah satu wujud hubungan antara perusahaan dengan pelanggan yaitu, pelanggan dapat terlibat dalam hubungan yang lebih dalam terhadap layanan perusahaan dan memiliki niat secara sukarela untuk membantu perusahaan dan juga pelanggan lain, dengan cara memberikan informasi terkait dengan perusahaan tersebut (Lishan Xie, Patrick Poon, Wenxuan Zhang, 2017).

Perusahaan berinteraksi dengan pelanggan dengan fokus agar kebutuhan pelanggan lebih terjamin dan memuaskan bagi pelanggan. Peningkatan interaksi pelanggan dengan perusahaan tersebut dinamakan peningkatan kualitas hubungan. Pada saat terjadi peningkatan kualitas hubungan antara pelanggan dengan perusahaan, pelanggan akan menunjukkan tingkat kepuasan, komitmen, kepercayaan, dan keintiman emosional yang tinggi pula terhadap perusahaan. Menurut teori pertukaran sosial, pelanggan merasa berkewajiban untuk membalas dan berkomitmen terhadap suatu hubungan ketika mendapatkan manfaat dari orang lain. Pelanggan cenderung akan melakukan perilaku yang positif, seperti menjadi 
sukarelawan untuk membantu layanan perusahaan (CCB) dan memberikan informasi terkait dengan layanan perusahaan kepada pelanggan lain.

Sejalan dengan penelitian yang dilakukan oleh Balaji (2014) yang menyatakan bahwa Kualitas Hubungan berpengaruh positif dan signifikan CCB. Dengan kata lain, peningkatan kualitas hubungan antara perusahaan dengan pelanggan berpengaruh positif terhadap CCB.

Hipotesis 1: Kualitas Hubungan berpengaruh secara signifikan terhadap CCB pada transportasi online Grab di Surabaya

\section{Pengaruh Persepsi Nilai terhadap Customer Citizenship Behavior (CCB)}

Nilai yang dirasakan oleh pelanggan dapat diberikan oleh pelanggan melalui interaksi pelanggan dengan produk maupun dengan produsen. Hasil dari interaksi antara pelanggan dan perusahaan dapat berupa penilaian terhadap produk maupun layanan yang didapat oleh pelanggan.

Konsumen akan mendapatkan nilai-nilai berupa termasuk kesan, harapan, dan kinerja pada suatu produk atau layanan. Semakin baik atau semakin positif nilai-nilai tersebut, konsumen akan memberikan respon berupa perilaku tertentu yang berkaitan dengan nilai yang didapatnya. Konsumen akan menunjukkan perilaku yang mengarah kepada peningkatan kontribusi interaksi yang positif dengan konsumen lainnya. Dengan kata lain, konsumen yang telah merasakan nilai positif dari sebuah layanan akan menunjukkan CCB kepada orang lain. Hal ini sejalan dengan penelitian yang dilakukan oleh Cheng et al. (2016) maupun Ali et al. (2015) yang menyatakan bahwa persepsi nilai berpengaruh signifikan terhadap CCB. Dengan demikian, maka peningkatan dari Persepsi Nilai akan mendorong pula peningkatan CCB.

Hipotesis 2: Persepsi Nilai berpengaruh secara signifikan terhadap CCB pada transportasi online Grab di Surabaya

\section{Pengaruh Kualitas Hubungan terhadap Kepuasan Pelanggan}

Kualitas hubungan yang baik akan memperbesar komitmen, kepercayaan, hubungan jangka panjang yang berkelanjutan antara pelanggan dan perusahaan. Selain itu, kualitas hubungan yang baik dapat menurunkan level konflik yang mungkin terjadi antara pelanggan dengan perusahaan. Dengan kata lain, bilamana hubungan baik terbina antara perusahaan dengan pelanggannya, maka pelanggan akan puas dikarenakan level konflik rendah, tingginya komitmen serta kepercayaan antar kedua belah pihak, serta terjadinya hubungan timbal balik dalam jangka panjang.

Pelanggan yang merasakan kualitas hubungan yang baik dengan perusahaan, maka pelanggan tersebut akan merasa lebih puas terhadap produk maupun layanan perusahaan. Tingkat kepuasan pelanggan yang tinggi akan menghasilkan profitabilitas bagi perusahaan. Pelanggan yang puas akan menilai reputasi perusahaan baik karena perusahaan komunikatif dan hal tersebut menjadikan pelanggan bertambah puas. Hal tersebut sejalan dengan penelitian yang dilakukan oleh Ilias Santouridis \& Androniki Veraki (2017) dan Balaji, et al (2014) yang berpendapat bahwa kualitas hubungan berpengaruh signifikan terhadap kepuasan konsumen.

Hipotesis 3: Kualitas Hubungan berpengaruh secara signifikan terhadap kepuasan pelanggan pada transportasi online Grab di Surabaya.

\section{Pengaruh Persepsi Nilai terhadap Kepuasan Pelanggan}

Peningkatan persepsi nilai dapat terjadi apabila perusahaan memberikan sesuatu yang tidak diberikan oleh perusahaan lain. Pelanggan yang membeli produk atau menggunakan sebuah layanan dari sebuah perusahaan bilamana diberikan pelayanan maupun mutu produk yang tidak didapatkan dari perusahaan lainnya dapat meningkatkan persepsi nilai yang 
maksimum oleh pelanggan dan pelanggan pun merasa puas (Abdulrauf Animashaun, Tarila Iman Tunkarimu dan Omkar Dastane, 2016).

Sehubungan dengan teori kepuasan pelanggan, intensitas kesadaran pelanggan terhadap kinerja suatu layanan terbentuk dari evaluasi layanan yang dilakukan oleh pelanggan setelah membandingkan antara kinerja nyata sebuah layanan dengan ekspektasi mereka sebelum menggunakan layanan. Hal tersebut sejalan dengan penelitian yang dilakukan oleh Ali et al. (2015) dan penelitian Raditha Hapsari, Michael Clemes, David Dean (2015) yang menyatakan bahwa persepsi nilai merupakan kunci dalam mendorong peningkatan kepuasan pelanggan. Dengan demikian, maka peningkatan pada persepsi nilai akan mendorong peningkatan pula pada kepuasan pelanggan.

Hipotesis 4: Persepsi Nilai berpengaruh secara signifikan terhadap kepuasan pelanggan pada transportasi online Grab di Surabaya.

\section{Pengaruh Kepuasan Pelanggan terhadap Customer Citizenship Behavior (CCB)}

Pelanggan yang merasa puas dengan kinerja perusahaan, mereka cenderung percaya bahwa perusahaan telah memberikan layanan prima kepada pelanggan. Apabila tingkat kepuasan pada pelanggan tinggi maka pelanggan akan terlibat secara sukarela untuk memberikan informasi yang bermanfaat kepada pelanggan lain, dimana perilaku tersebut dianggap penting untuk keberhasilan suatu perusahaan (Yi, Gong, \& Lee, 2013). Perilaku pelanggan semacam ini dinamakan CCB.

Pelanggan yang sudah merasa puas dengan kinerja perusahaan cenderung khawatir mengenai kesejahteraan perusahaan dan pelanggan bersedia untuk membalas usahanya dengan menampilkan perilaku CCB yang berarti bagi perusahaan. Hal ini sejalan dengan penelitian yang dilakukan oleh Penelitian yang dilakukan oleh Estelle van Tonder \& Leon T. de Beer (2018) yang menyatakan bahwa kepuasan pelanggan berpengaruh langsung dan signifikan terhadap CCB. Dengan demikian, peningkatan kepuasan pelanggan akan memberi pengaruh pada peningkatan CCB.

Hipotesis 5: Kepuasan Pelanggan berpengaruh secara signifikan terhadap CCB pada transportasi online Grab di Surabaya.

\section{Pengaruh Kualitas Hubungan terhadap Customer Citizenship Behavior (CCB) yang dimediasi oleh Kepuasan Pelanggan}

Kualitas hubungan antara pelanggan dengan perusahaan yang berjalan dengan baik akan memperbesar komitmen, kepercayaan, hubungan jangka panjang yang berkelanjutan antara pelanggan dan perusahaan. Selain itu, kualitas hubungan yang baik dapat menurunkan level konflik yang mungkin terjadi antara pelanggan dengan perusahaan. Di sisi lain, kualitas hubungan yang baik antara pelanggan dengan perusahaan turut memberikan pengaruh kepada perilaku pelanggan dimana pelanggan akan berusaha terlibat lebih dalam kepada layanan perusahaan dan memiliki niat secara sukarela untuk membantu perusahaan dan juga pelanggan lain (Lishan Xie, Patrick Poon, Wenxuan Zhang, 2017).

Hal tersebut sejalan dengan hasil penelitian yang dilakukan oleh Balaji (2014), Estelle van Tonder \& Leon T. de Beer (2018) menunjukkan bahwa Kualitas Hubungan berpengaruh positif dan signifikan terhadap CCB. Dengan demikian, kualitas hubungan dapat memberikan pengaruh positif kepada kepuasan pelanggan dan juga kepada CCB. Pada penelitian Ilias Santouridis \& Androniki Veraki (2017) menunjukkan bahwa kepuasan pelanggan berpengaruh langsung dan signifikan terhadap CCB. Pengaruh ini memperbesar pengaruh langsung kualitas hubungan terhadap $\mathrm{CCB}$ sehingga dengan demikian maka kepuasan memediasi pengaruh kualitas hubungan terhadap CCB. Dengan demikian, peningkatan kepuasan sekaligus kualitas hubungan memberi pengaruh terhadap CCB. 
Hipotesis 6: Kepuasan Pelanggan memediasi pengaruh kualitas hubungan terhadap CCB pada transportasi online Grab di Surabaya.

\section{Pengaruh Persepsi Nilai terhadap Customer Citizenship Behavior (CCB) yang dimediasi oleh Kepuasan Pelanggan}

Penelitian yang dilakukan oleh Cheng et al. (2016) menunjukkan bahwa persepsi nilai berpengaruh signifikan terhadap CCB. Artinya, semakin tinggi persepsi nilai yang dirasakan pelanggan akan mendorong munculnya perilaku pelanggan dimana pelanggan akan aktif berperan serta memberikan informasi dan berperilaku lain yang menguntungkan bagi perusahaan. Dengan demikian, maka persepsi nilai berpengaruh signifikan terhadap CCB.

Persepsi nilai yang tinggi juga akan menyebabkan pelanggan merasa puas, yaitu pelanggan merasakan harapannya terlampaui oleh kualitas produk maupun kualitas layanan yang disediakan perusahaan. Pada penelitian Estelle van Tonder \& Leon T. de Beer (2018) menunjukkan bahwa kepuasan pelanggan berpengaruh langsung dan signifikan terhadap CCB. Pengaruh ini memperbesar pengaruh langsung persepsi nilai terhadap CCB sehingga dengan demikian maka kepuasan pelanggan memediasi pengaruh persepsi nilai terhadap CCB.

Hipotesis 7: Kepuasan Pelanggan memediasi pengaruh persepsi nilai terhadap CCB pada transportasi online Grab di Surabaya.

\section{Gambar 2 \\ Kerangka Pemikiran}

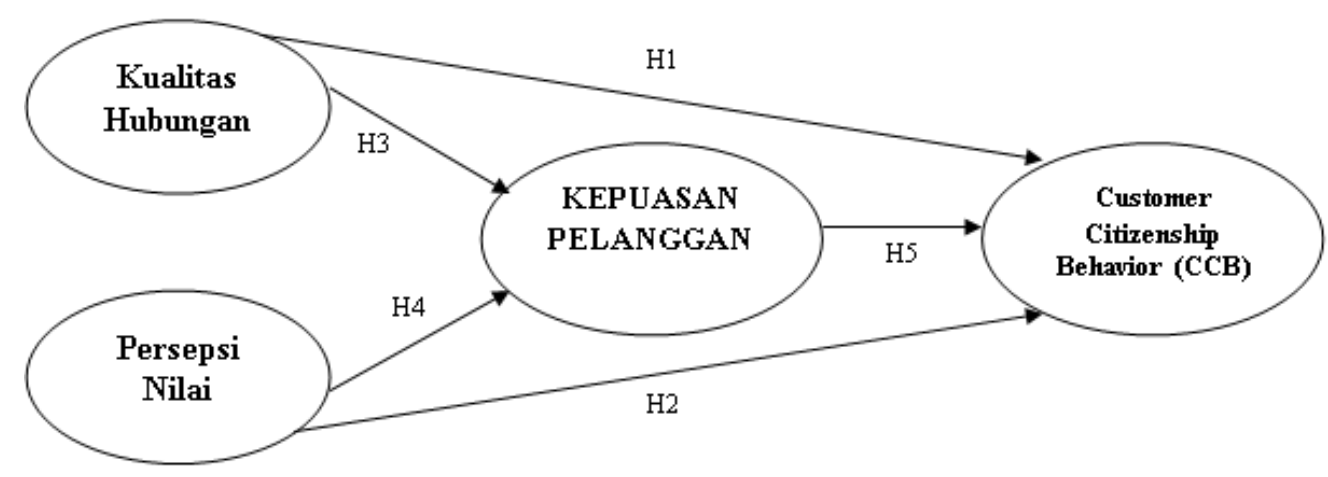

\section{METODE PENELITIAN}

\section{Klasifikasi Sampel}

Sampel yang digunakan dalam penelitian ini adalah pengguna layanan transportasi online Grab di wilayah Surabaya dengan kriteria responden sebagai berikut: (1) Pengguna layanan grab, (2) Minimal 1 kali menggunakan layanan Grab dalam tiga bulan terakhir, (3) Berusia minimal 18 tahun, (4) Berada di wilayah Surabaya.

Jumlah sampel yang digunakan pada penelitian yaitu sebanyak 200 responden, sedangkan teknik pengambilan sampel yang digunakan dalam penelitian ini menggunakan metode purposive sampling.

\section{Data Penelitian}

Data yang digunakan pada penelitian ini adalah data primer. Data yang digunakan dalam penelitian ini diperoleh melalui metode penyebaran kuesioner. Dalam kuesioner terdapat pertanyaan-pertanyaan yang secara logis berhubungan secara langsung dengan masalah penelitian dan setiap pertanyaan merupakan jawaban-jawaban yang mempunyai 
makna dalam menguji hipotesa. Dibandingkan dengan interview guide, daftar pertanyaan atau kuesioner lebih mudah, terperinci dan lengkap.

\section{Alat Analisis}

Data yang terkumpul selanjutnya akan dilakukan analisis data. Alat analisis data yang digunakan dalam penelitian ini yaitu menggunakan regresi Partial Least Square (PLS), yang diolah dengan menggunakan bantuan program WarpPLS 6.0. PLS merupakan sebuah teknik analisis data yang dapat digunakan untuk membantu memudahkan pengolahan data, menghitung dan menganalisis data statistik bahkan pada variabel independen yang jumlahnya banyak dan terjadi gejala multikolinearitas pada variabel-variabel tersebut.

\section{HASIL DAN PEMBAHASAN}

Berikut ini adalah model persamaan struktural yang telah dianalisa menggunakan program WarpPLS 6.0. Model tersebut telah diuji dengan berbagai asumsi dan persyaratan sebelumnya sekaligus menggambarkan pembuktian seluruh hipotesis yang diajukan dalam penelitian ini. Koefisien jalur dapat digambarkan secara eksplisit pada gambar berikut ini :

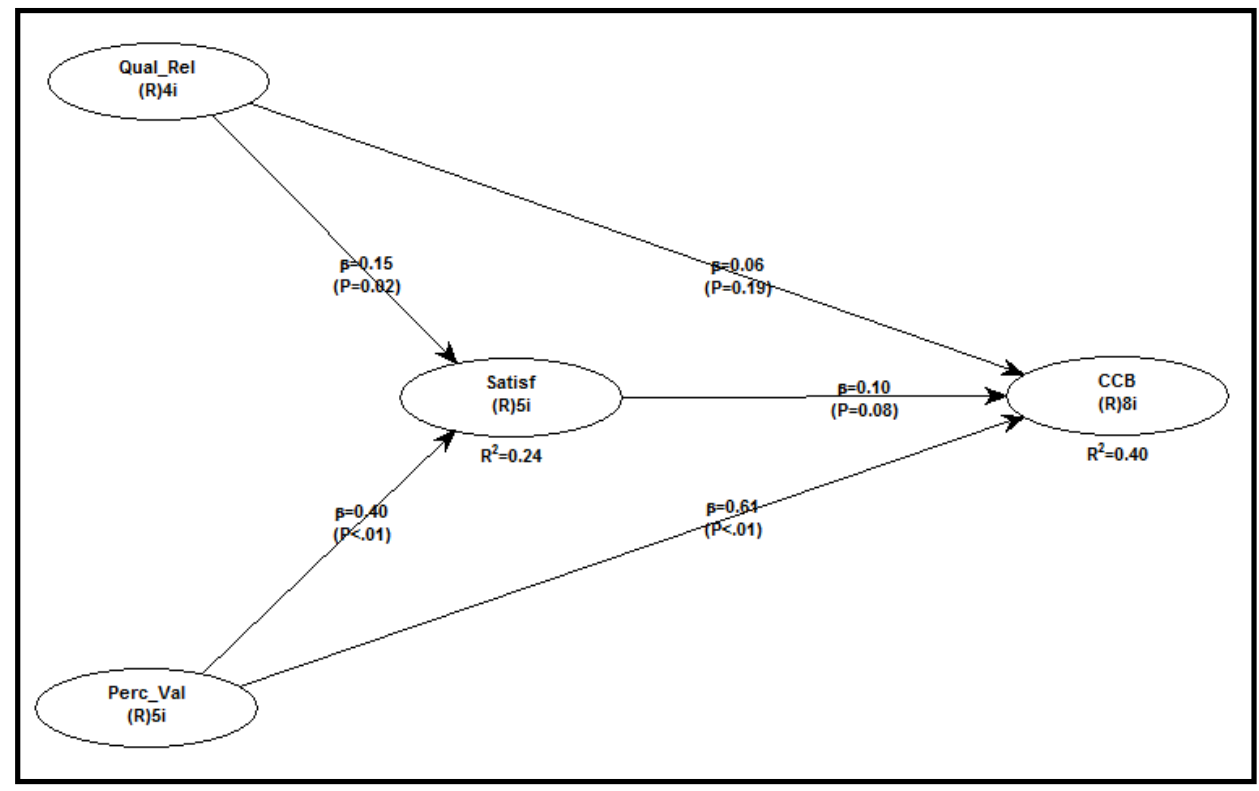

\section{Gambar 3}

HASIL ESTIMASI PENGARUH ANTAR VARIABEL

Berdasarkan tampilan dari gambar yang dihasilkan pada program Warp-PLS tersebut diperjelas dengan keterangan pada tabel berikut ini.

Tabel 1

Koefisien Jalur Model Persamaan Struktural

\begin{tabular}{lll}
\hline Hubungan & Loading & P Value \\
$\mathrm{KH}=>\mathrm{CCB}$ & 0,061 & 0,191 \\
$\mathrm{PN}=>\mathrm{CCB}$ & 0,606 & $<0,001$ \\
$\mathrm{KH}=>\mathrm{KP}$ & 0,146 & 0,017 \\
$\mathrm{PN}=>\mathrm{KP}$ & 0,4 & $<0,001$ \\
$\mathrm{KP}=>\mathrm{CCB}$ & 0,098 & 0,079 \\
\hline
\end{tabular}




\section{Hipotesis ke-1}

Hipotesis ke 1 yaitu, Kualitas Hubungan berpengaruh secara signifikan terhadap CCB pada transportasi online Grab di Surabaya. Hasil perhitungan pada Tabel 1 memperlihatkan bahwa Kualitas hubungan berpengaruh langsung sebesar 0,061 terhadap Customer Citizenship Behavior (CCB). Pengaruh positif ini tidak signifikan karena dukungan $p$ value sebesar 0,191 nilainya lebih besar dari 0,05 dan hipotesis pertama $\left(\mathrm{H}_{1}\right)$ tidak terbukti dan teruji kebenarannya. Artinya, peningkatan atau penurunan kualitas hubungan tidak memberi pengaruh terhadap peningkatan atau penurunan Customer Citizenship Behavior (CCB). Hubungan antara layanan perusahaan Grab memang tinggi tetapi hal tersebut tidak terwujud antara konsumen dengan para sopir atau pengemudi Grab di lapangan. Dengan kata lain, kualitas hubungan yang tinggi tersebut tidak menyentuh kepada layanan perusahaan penyedia atau operator Grab, tetapi lebih kepada hubungan antara konsumen dengan pengemudi Grab. Berdasarkan pengamatan, pengemudi Grab biasanya hanya bekerja sesuai pesanan untuk mengantarkan penumpang ke lokasi, sementara tuntunan dan instruksi dasar berasal dari perusahaan yang bekerja di balik aplikasi. Tentu saja, Customer Citizenship Behavior (CCB) yang sudah terbentuk pada konsumen lebih kepada perilaku konsumen kepada perusahaan, bukan merupakan peranan dari keaktifan pengemudi Grab. CCB yang telah terbentuk lebih kepada layanan dari perusahaan di balik aplikasi Grab yang mengendalikan hubungan tersebut.

\section{Hipotesis ke-2}

Hipotesis ke 2 yaitu, Persepsi Nilai berpengaruh secara signifikan terhadap CCB pada transportasi online Grab di Surabaya. Hasil perhitungan pada Tabel 1 memperlihatkan bahwa Persepsi nilai berpengaruh langsung sebesar 0,606 terhadap Customer Citizenship Behavior (CCB). Pengaruh positif ini signifikan karena $p$ value sebesar $<0,001$ nilainya lebih kecil dari 0,05 dan hipotesis kedua $\left(\mathrm{H}_{2}\right)$ dapat terbukti dan teruji kebenarannya. Artinya, peningkatan atau penurunan persepsi nilai memberi pengaruh signifikan terhadap peningkatan atau penurunan Customer Citizenship Behavior (CCB). Hasil ini sejalan dengan observasi di dunia nyata dimana para pelanggan layanan Grab umumnya mengevaluasi bahwa layanan Grab adalah layanan yang berharga. Pelanggan awalnya mencoba meng-instal layanan tersebut pada smartphone masing-masing, tetapi karena manfaatnya yang besar maka pelanggan merasa bahwa layanan Grab sesuai atau bahkan melebihi dengan harapan yang sudah dibuat.

\section{Hipotesis ke-3}

Hipotesis ke 3 yaitu, Kualitas Hubungan berpengaruh secara signifikan terhadap kepuasan pelanggan pada transportasi online Grab di Surabaya. Hasil perhitungan pada Tabel 1 memperlihatkan bahwa Kualitas hubungan berpengaruh positif sebesar 0,146 terhadap kepuasan pelanggan. Pengaruh secara langsung ini signifikan karena dukungan $p$ value sebesar 0,017 nilainya lebih besar dari 0,05 dan hipotesis ketiga $\left(\mathrm{H}_{3}\right)$ dapat terbukti dan teruji kebenarannya. Artinya, peningkatan atau penurunan kualitas hubungan memberi pengaruh signifikan terhadap peningkatan atau penurunan Kepuasan Pelanggan. Hubungan yang menawarkan kualitas yang unggul akan menciptakan kepuasan bagi para pengguna layanan Grab. Dengan adanya hal tersebut maka, pihak Grab harus lebih memahami faktorfaktor yang mempengaruhi hubungan pelanggan dengan perusahaan. Salah satu upaya yang dilakukan oleh Grab yaitu terus meningkatkan keamanan bagi para pengguna layanan Grab dan mitra pengemudi layanan Grab. Selain itu, Grab juga terus melakukan edukasi maupun pelatihan kepada para mitranya sehingga mereka dapat mengetahui cara untuk menjalin hubungan yang baik dengan pelanggan Grab. Sehingga diharapkan dengan adanya kualitas yang unggul dari layanan Grab dapat meningkatkan kepuasan pelanggan. 


\section{Hipotesis Ke-4}

Hipotesis ke 4 yaitu, Persepsi Nilai berpengaruh secara signifikan terhadap kepuasan pelanggan pada transportasi online Grab di Surabaya. Hasil perhitungan pada Tabel 1 memperlihatkan bahwa Persepsi nilai berpengaruh langsung sebesar 0,4 terhadap kepuasan pelanggan. Pengaruh positif ini signifikan karena $p$ value sebesar $<0,001$ nilainya lebih kecil dari 0,05. Artinya, peningkatan atau penurunan Persepsi Nilai memberi pengaruh signifikan terhadap peningkatan atau penurunan Kepuasan Pelanggan. Pengguna layanan transportasi Grab yang telah merasakan manfaat terhadap nilai yang ada pada layanan Grab, pelanggan akan berpersepsi bahwa Grab merupakan sebuah layanan yang memiliki nilai bagi aktivitasnya. Bilamana perspektif nilai Grab telah yang dirasakan oleh pelanggan telah dicapai dengan baik naik dari perspektif ekonomi, perspektif emosional, dan perspektif nilai sosial, maka pelanggan akan mempersepsikan bahwa harapannya terpenuhi melalui layanan Grab, atau dengan kata lain kepuasan pelanggan tercapai.

\section{Hipotesis Ke-5}

Hipotesis ke 5 yaitu, Kepuasan Pelanggan berpengaruh secara signifikan terhadap CCB pada transportasi online Grab di Surabaya. Hasil perhitungan pada Tabel 1 memperlihatkan bahwa Kepuasan pelanggan berpengaruh langsung sebesar 0,098 terhadap Customer Citizenship Behavior (CCB). Pengaruh positif ini tidak signifikan karena $p$ value sebesar 0,079 yang nilainya lebih besar dari 0,05. Artinya, Pada penelitian ini kepuasan tidak berpengaruh terhadap CCB dikarenakan perusahaan Grab adalah perusahaan berjenis bisnis online yang mana pelanggan dan perusahaan tidak dimungkinkan dapat bertemu. Pelanggan hanya bertemu dengan mitra dari perusahaan Grab saja. Hal inilah yang tidak memungkinkan untuk terjadinya bahwa kepedulian pelanggan tidak tersalurkan karena tidak dapat terjadi tatap muka dengan pengelola Grab yang bekerja di balik layar hanya untuk menjalankan para mitranya yang bergerak sebagai pengemudi. Selain itu, pelanggan yang merasa puas terhadap layanan Grab belum tentu melakukan CCB kepada orang lain karena sebagian besar masyarakat Indonesia telah mengetahui reputasi dari Grab sehingga pelanggan Grab tidak melakukan CCB kepada orang lain.

\section{Hipotesis Ke- 6 dan 7}

Hipotesis Ke-6 dan 7 dapat dihitung dengan melakukan evaluasi pada hasil perhitungan WarpPLS dan menghitungnya ke dalam perhitungan VAF (Variance Accounted For). VAF merupakan ukuran seberapa besar variabel pemediasi mampu menyerap pengaruh langsung dari model tanpa pemediasi. VAF dihitung dengan rumus :

Dimana :

$$
\mathrm{VAF}=\frac{P_{12} \cdot P_{23}}{P_{12} \cdot P_{23}+P 13}
$$

$\mathrm{P} 12 \times \mathrm{P} 23=$ pengaruh tidak langsung eksogen melalui pemediasi

$\mathrm{P} 12=\quad$ koefisien jalur variabel eksogen-i terhadap pemediasi

$\mathrm{P} 23=$ koefisien jalur pemediasi terhadap variabel endogen.

P13 = koefisien pengaruh langsung variabel eksogen-i terhadap variabel endogen (model awal tanpa menyertakan pemediasi) 
Sehingga VAF dapat dihitung sebagai berikut:

Tabel 2.

Perhitungan Pengaruh Mediasi

\begin{tabular}{|c|c|c|}
\hline Pengaruh antar Variabel & Mediasi dari Kualitas Hubungan & Mediasi dari Persepsi Nilai \\
\hline P13 & 0.049 & 0.567 \\
P12 & 0.146 & 0.4 \\
P23 & 0.098 & 0.098 \\
P12 x P23 & 0.014308 & 0.0392 \\
\hline VAF & $22.60 \%$ & $6.47 \%$ \\
\hline
\end{tabular}

Hipotesis ke 6 yaitu, Kepuasan Pelanggan memediasi pengaruh kualitas hubungan terhadap CCB pada transportasi online Grab di Surabaya. Hasil perhitungan VAF pada model mediasi hipotesis ke-6 yaitu sebesar 22,60\% (VAF berada pada rentang $(20 \%<\mathrm{VAF}<80 \%$ ), artinya kepuasan konsumen memiliki peran mediasi secara parsial dalam pengaruh kualitas hubungan terhadap Customer Citizenship Behavior (CCB). Artinya, hasil interpretasi dan analisa data memperlihatkan bahwa Kepuasan Pelanggan memberi pengaruh mediasi secara parsial pada hubungan kualitas hubungan dengan Customer Citizenship Behavior (CCB). Hal ini diperkuat dengan bukti bahwa pengaruh langsung Kualitas Hubungan terhadap Customer Citizenship Behavior (CCB) yang tidak signifikan dan kepuasan pelanggan berpengaruh langsung tidak signifikan terhadap Customer Citizenship Behavior (CCB). Dengan kata lain, pengaruh Kualitas Hubungan yang tidak signifikan terhadap Customer Citizenship Behavior (CCB) akan menjadi signifikan setelah ditambahkan sebagian pengaruh dari kepuasan pelanggan.

Hipotesis ke 7 yaitu, Kepuasan Pelanggan memediasi pengaruh persepsi nilai terhadap CCB pada transportasi online Grab di Surabaya. Hasil perhitungan VAF pada model mediasi hipotesis ke7 yaitu sebesar $6,47 \%$ (VAF berada pada rentang (VAF < 20\%), artinya kepuasan konsumen tidak memiliki peran mediasi sama sekali dalam pengaruh persepsi nilai terhadap Customer Citizenship Behavior (CCB). Artinya, Hasil interpretasi dan analisa data memperlihatkan bahwa Kepuasan Pelanggan tidak memberi pengaruh mediasi secara parsial maupun secara keseluruhan pada hubungan Persepsi Nilai dengan Customer Citizenship Behavior (CCB). Hal ini diperkuat dengan bukti bahwa Persepsi nilai berpengaruh langsung dan signifikan terhadap Customer Citizenship Behavior (CCB), namun kepuasan pelanggan berpengaruh tidak signifikan terhadap Customer Citizenship Behavior (CCB). Dengan kata lain, pengaruh persepsi nilai yang sudah signifikan terhadap Customer Citizenship Behavior (CCB) tidak memerlukan tambahan sebagian atau seluruh pengaruh dari kepuasan pelanggan.

\section{PENUTUP}

\section{Kesimpulan}

Berdasarkan hasil analisa data dan pembahasan yang dilakukan, maka kesimpulan pada penelitian ini adalah sebagai berikut :

1. Kualitas hubungan berpengaruh tidak signifikan terhadap Customer Citizenship Behavior (CCB). Artinya, peningkatan atau penurunan kualitas hubungan tidak memberi pengaruh terhadap peningkatan atau penurunan Customer Citizenship Behavior (CCB). 
2. Persepsi nilai berpengaruh positif dan signifikan terhadap Customer Citizenship Behavior (CCB). Artinya, peningkatan atau penurunan persepsi nilai memberi pengaruh signifikan terhadap peningkatan atau penurunan Customer Citizenship Behavior (CCB).

3. Kualitas Hubungan berpengaruh positif dan signifikan terhadap Kepuasan Pelanggan. Artinya, peningkatan atau penurunan Kualitas Hubungan memberi pengaruh signifikan terhadap peningkatan atau penurunan Kepuasan Pelanggan.

4. Persepsi Nilai berpengaruh positif dan signifikan terhadap Kepuasan Pelanggan. Artinya, peningkatan atau penurunan Persepsi Nilai memberi pengaruh signifikan terhadap peningkatan atau penurunan Kepuasan Pelanggan.

5. Kepuasan Pelanggan berpengaruh tidak signifikan terhadap Customer Citizenship Behavior (CCB). Artinya, peningkatan atau penurunan Kepuasan Pelanggan tidak dapat memberi pengaruh signifikan terhadap peningkatan atau penurunan Customer Citizenship Behavior (CCB).

6. Kepuasan Pelanggan memberi pengaruh mediasi secara parsial pada hubungan kualitas hubungan dengan Customer Citizenship Behavior (CCB). Dengan kata lain, pengaruh Kualitas Hubungan yang tidak signifikan terhadap Customer Citizenship Behavior (CCB) akan menjadi signifikan setelah ditambahkan sebagian pengaruh dari kepuasan pelanggan.

7. Kepuasan Pelanggan tidak memberi pengaruh mediasi secara parsial maupun secara keseluruhan pada hubungan Persepsi Nilai dengan Customer Citizenship Behavior (CCB). Dengan kata lain, pengaruh persepsi nilai yang sudah signifikan terhadap Customer Citizenship Behavior (CCB) tidak memerlukan tambahan sebagian atau seluruh pengaruh dari kepuasan pelanggan.

\section{DAFTAR PUSTAKA}

Ali, Rizwan; Leifu, Gao; Rafiq, Muhammad Yasir; Mudassar, H. (2015). Role Of Perceived Value, Customer Expectation, Corporate Image And Perceived Service Quality On The Customer Satisfaction . The Journal of Applied Business Research Vol. 31 No.4, 1425-1436.

Animashaun, A., Iman, T., Dastane, Omkar. (2016). "Customer Perceived Value Towards Convenience Stores in Malaysia: The Influence on Customer Satisfaction,Loyalty and Retention". Journal of Marketing and Consumer Behaviour in Emerging Markets 2(4), 4-27.

Anaza, N. A. (2017). Personality Antecedents of Customer Citizenship Behaviors in Online Shopping Situations. Psychology and Marketing. Vol 31, 251-263.

Balaji M.S. (2014). "Managing customer citizenship behavior: a relationship perspective". Journal of Strategic Marketing Vol 22, 222-239.

Cheng, Chang Jui; Luo, She Juang; Yen, Chang Hua; Yang, Ya Fang. (2016). "Brand attachment and customer citizenship behaviors". The Service Industries Journal Vol. 36, 263-277

Chiu, Weisheng; Shin, Sunyun; Lee, Hyun Woo. (2017). "Value Co-Creation in Fitness Centers: The Role of Customer Citizenship Behavior on Perceived Value, Satisfaction, and Repurchase Intention". IGI Global, 415-430.

Fernandes, Solimun; Rinaldo, Adji Achmad; Nurjannah. 2017. Metode Statistika Multivariat: Pemodelan Persamaan Struktural (SEM). Cetakan kedua. Penerbit UB Press. Malang.

Hapsari, R., Clemes, M., \& Dean, D. (2016). The Mediating Role of Perceived Value on the Relationship. Procedia Economics and Finance 35, 388 - 395.

H, Matti Juhani; Martinsuo, Mia; Naumann, Earl. (2014). "Drivers of customer satisfaction and relationship quality in system delivery projects". Journal of Strategic Marketing Vol. 21, No. 7, 613-636. 
Imam Ghozali. (2016). Aplikasi Analisis Multivariete. Semarang: Badan Penerbit Universitas Diponegoro

Imam Ghozali. (2014). Partial Least Square Konsep, Metode Dan Aplikasi Menggunakan

Noor Juliansyah. (2011). Metodologi Penelitian. Jakarta: Prenada Media Group.

Santouridis, Ilias; Veraki, Androniki. (2017). "Customer relationship management and customer satisfaction: the mediating role of relationship quality". Total Quality Management \& Business Excellence Vol. 28 No. 10. 1122-1133.

Sugiyono. (2012). Metode Penelitian Kuantitatif, Kualitatif, dan R\&D. Bandung: Alfabeta.

Tonder, Estelle Van; de Beer, Leon T.(2017). "New perspectives on the role of customer satisfaction and commitment in promoting customer citizenship behaviours". South African Journal of Economic and Management Sciences, 1-11.

https://www.idntimes.com/business/economy/putriana-cahya/persaingan-tiga-transportasi-onlineterbesar/full. Diakses tanggal 2 Desember 2018.

https://www.validnews.id/Ketika-Grab-MengUber-Go-Jek-sgq. Diakses tanggal 2 Desember 2018. 